\title{
The effect of learning culture on self-efficacy of special intelligent students in senior high school
}

\author{
Ananda Aprilia*), Siti Masyithoh, Mu'arif SAM \\ Faculty of Tarbiyah and Teacher Science, Universitas Islam Negeri Syarif Hidayatullah Jakarta, Indonesia
}

\begin{tabular}{l} 
Article Info \\
\hline Article history: \\
Received Sep $18^{\text {th }}, 2021$ \\
Revised Oct $24^{\text {th }}, 2021$ \\
Accepted Nov $06^{\text {th }}, 2021$
\end{tabular}

\section{Keyword:}

Learning culture

Self-efficacy

Special intelligent students

\begin{abstract}
Special intelligent students are excellent human resources and are expected to make a major contribution to people's lives, including achievement in the academic field. With this extraordinary intelligence, special intelligent students should have high self-efficacy, but they are often found who are not confident in their abilities and have an impact on the learning achievement that is not optimal. This is because there are still some of them who do not have a good learning culture. This study aims to analyze the contribution of learning culture to the self-efficacy on special intelligent students in senior high school. This research was used a quantitative method with sampling based on the simple random sampling technique developed by Isaac and Michael. Data were collected using questionnaires, interviews, and documentation studies. Based on SPSS Ver.22 data processing, the results of the correlation test (r-test) show that there is a significant correlation between learning culture and self-efficacy of special intelligent students in a very strong and unidirectional level. The result shows that learning culture has a positive effect on the self-efficacy of special intelligent students. In the calculation of the coefficient of determination, it is known that the effect of learning culture on the self-efficacy of special intelligent students is $68.6 \%$, while the remaining $31.4 \%$ is influenced by other factors not examined. It can be concluded that learning culture has a positive effect on the self-efficacy of special intelligent students. The better learning culture of special intelligent students, the higher their self-efficacy.
\end{abstract}

(C) 2021 The Authors. Published by IICET.

This is an open access article under the CC BY-NC-SA license

(https://creativecommons.org/licenses/by-nc-sa/4.0

\section{Corresponding Author:}

Ananda Aprilia

Universitas Islam Negeri Syarif Hidayatullah Jakarta

Email: anandaapriliaa@gmail.com

\section{Introduction}

Every citizen has the same rights in life, including obtaining educational services. The right to education belongs to all without exception, including children with special needs. Children who have specialties have the right to receive educational services according to their needs but still live together in natural social situations. The government has attempted to facilitate the regulation of education in order to provide services to all students with the issuance of Law no. 20 of 2003 concerning the National Education System, namely: Article 5 paragraph (4), "Citizens who have the potential for intelligence and special talents are entitled to special education." Thus, the government mandates the need to provide special education for students who have the potential for special intelligence. This is done so that the potential possessed by students can develop optimally so that they can grow into human beings who believe, fear God Almighty, have noble character, are knowledgeable, capable, creative, and independent. 
In addition, the government has also made efforts to provide educational services for students who have the potential for special intelligence. The service program for special intelligent students that developed first was Grade-Based-Acceleration where students can complete their study period faster than their peers (Deden Saipul Hidayat and Wawan Gunawan, 2013). Currently, special education services for special intelligent students can be implemented in an accelerated program with diversification, including: special education or special schools for special intelligent students, special classes for example in the form of accelerated classes, or special learning for example through a credit system with a learning load (credits). more. In 2015, special education services in the form of accelerated classes were abolished by the Ministry of Education and Culture, instead the Semester Credit System (SKS) program was implemented to facilitate the learning speed and intelligence of different students.

In the world of education, Renzulli is a well-known figure with the theory that underlies the understanding of special intelligence (Renzulli, 2002, 2012; Renzulli \& D'Souza, 2014). According to him, special intelligent students are students who have above average intelligence abilities, have creativity and high commitment to assignments (Nanang Rosadi and Iwan Wahyu Widayat, 2013). This understanding of Renzulli is known as The Three Rings of Renzulli or the Three Rings of Renzulli. The addition of creativity and commitment to tasks in the definition of special intelligence indicates that there are other performances outside of traditional intelligence measures. Students who get special intelligent category because of high IQ scores can stop being special intelligent students; On the other hand, students who are not special intelligent can become special intelligent because of their creativity and commitment to the task (Rini Sugiarti, 2019).

Special intelligent students are excellent human resources and are expected to make a major contribution to people's lives, including achievement in the academic field. With this extraordinary intelligence, special intelligent students should have high self-efficacy and high learning achievement, but they are often found who are not confident in their abilities so they cannot show extraordinary achievements.

Bandura is a figure who introduced the term self-efficacy or self-efficacy (Bandura, 2006; Bandura, Freeman, \& Lightsey, 1999). This concept is widely adopted for various purposes, especially in terms of learning. Bandura uses the term self-efficacy to refer to beliefs or beliefs about one's abilities (Abd. Mukhid, 2009). Selfefficacy is an individual's assessment or belief in their abilities. Self-efficacy can lead to different behaviors between individuals even though they have the same ability, because self-efficacy affects choices, goals, problem solving, and persistence in trying. Therefore, special intelligent students with the same level of ability make it possible to get different learning achievements because of their level of self-efficacy.

The results of Febriana and Desi's research with the title Relationship of Self Efficacy with Accelerated Student Learning Achievement (2013) show that in accelerated learning classes there are still students who have not been able to show optimal learning achievement. Less than optimal learning achievement is due to the lack of students' self-efficacy towards their abilities. Silvia Wulandari and Mira Aliza's research entitled Self-Efficacy and Academic Stress in Acceleration Program High School Students (2014) also revealed that students with high intelligence have ease to experience academic stress, are easily frustrated, feel tense, and even lose their confidence to live up to the demands of life. faced, especially in terms of academic competition. The results of this study show that self-efficacy has an effect of $59 \%$ on academic stress in special intelligent students.

It was further stated that there are several internal problems that special intelligent students have, including; self-doubt, poor self-image, excessive self-anxiety, critical thinking skills can lead to doubts (skepticism) towards themselves and others, creative abilities and interest in doing new things can cause them to dislike or boredom towards certain tasks, indifference and laziness can arise because the teaching given at school does not invite challenges for him (Deden Saipul Hidayat and Wawan Gunawan, 2013). Special intelligent students with low achievement also have characteristics of lack of motivation/goal, low self-confidence, low selfesteem, and inability to survive. This low learning achievement is due to the lack of students' self-efficacy towards their abilities.

Stanhope \& Bell (Nur Eva and Moh. Bisri, 2018) explain that special intelligent students who become underachievers can also be caused by overprotective parental behavior patterns or too pressure on children to show achievements. Sometimes there is material that students do not understand because the teacher is too quick to explain. Teachers and parents also find it difficult to help special intelligent students develop socialization skills. In addition, the effect of peers hinders their learning achievement, such as inviting children to play and lack of acceptance of children who are serious about learning.

So far, special intelligent students are considered as smart students and can face various difficult situations because they have high intelligence compared to ordinary students, even they are considered as students who do not have problems. However, a number of facts above show that special intelligent students also have the 
same problems as ordinary students, even tend to be more complex, both in terms of social, emotional, and personality. The existence of doubts about oneself and one's abilities, low self-confidence, poor self-image, excessive anxiety, weak commitment to tasks, inability to survive, and not optimal learning achievements are indications of low self-efficacy of intelligent students. special.

According to Bandura, self-efficacy in each individual will differ from one another based on three dimensions, namely level, strength, and generality (M. Ghufron and Rini Risnawita, 2012). This is supported by the opinion of Gist and Mitchell (M. Ghufron and Rini Risnawita, 2012) who argue that self-efficacy can lead to different behaviors among individuals with the same ability, because self-efficacy affects choices, goals, problem solving, and persistence in trying. . Therefore, the self-efficacy possessed by students, both ordinary students and special intelligent students, will certainly be different. Even the self-efficacy between special intelligent students and other special intelligent students will also be different, even though they have the same intelligence or ability.

In difficult situations, individuals with low self-efficacy tend to give up easily and consider themselves unable to do something around them. Meanwhile, individuals with high self-efficacy will try harder to overcome the existing challenges. Bandura (2006) suggested that one of the factors that effect self-efficacy is cultural factors. Culture effects self-efficacy through values, beliefs, and self-regulatory processes that serve as sources of self-efficacy assessment and consequences of self-efficacy beliefs. Culture obtained through the learning process by a person or group of people in their environment can develop into a learning culture.

Tabrani Rusyan (2007) suggests learning culture is a series of activities in carrying out the learning tasks carried out. Students make learning a habit, hobby, and pleasure, so that learning motivation arises from within which ultimately increases learning productivity. In this regard, learning culture is interpreted as learning habits carried out by individuals in carrying out their learning tasks.

The learning culture applied by special intelligent students is inseparable from the learning environment that shapes them, namely the school. Schools that have a strong organizational culture and are based on certain values and norms will affect the learning culture of their students. Therefore, to build a learning culture for students, it must be started from building the culture of the organization (school) concerned. The existence of a learning culture is one of the efforts to improve the quality of learning, because with a learning culture all learning activities and assignments will be organized and directed, so that the expected learning objectives can be achieved properly.

Tabrani Rusyan (2007) emphasized that learning culture is one of the efforts to improve the quality of learning, because with a learning culture all learning activities and assignments will be organized and directed so that the expected learning objectives will be achieved properly. The application of a good learning culture includes: a culture of compliance, an innovative culture, a professional culture, a culture of achievement, a culture of satisfaction, and a culture of integrity. A negative and wrong culture in the world of education will affect the development and growth of children so that a learning culture is needed. The learning culture that is formed in a learning area, namely the school, will later be able to regulate a pattern of behavior, interaction patterns, learning patterns and even the character of students as expected. Slameto (2018) argues that many students fail to learn because they do not have a good learning culture. A poor learning culture will shape students into lazy individuals, act on their own, and disorganized.

In the midst of many schools that have not implemented a good learning culture, there is a school that has tried to implement a good learning culture, namely SMAN 78 Jakarta. This is evidenced by the many academic and non-academic achievements both at the National and International levels that have been achieved. This school was also designated as an RSBI (International Standard School Pioneer) school in 2006 although it has now been abolished. SMAN 78 Jakarta is an educational institution that prepares its graduates for the best universities at the national and international level and is a school that provides a two-year service, namely the accelerated learning program for special intelligent students through the Semester Credit System (SKS). The culture applied at SMAN 78 Jakarta emphasizes Strengthening Character Education (PPK) by habituation of positive attitudes and behaviors in schools to build the identity of students in accordance with values, norms, and ethics through the development of school culture in the form of religious culture, culture of character, culture achievement, and a culture of loving the environment. This culture is a reflection of the formation of a good learning culture for special intelligent students.

The problems that occur are that the individual services provided by teachers to special intelligent students in heterogeneous classes are not maximized, teachers find it difficult to make learning modules for special intelligent students, the school's low effort in anticipating the self-development of special intelligent students in terms of social and emotional, high achievement pressure given parents, teachers, and schools to special intelligent students. 
Another problem that occurs is that not all of the special intelligent students apply the learning culture well. This causes special intelligent students who are unable to adapt to the two-year service, lack of self-confidence, self-doubt, excessive self-anxiety, feeling stressed and depressed, fear of not meeting expectations, and feeling down when facing failure, which indicates that there are still special intelligent students who have low selfefficacy.

Thus, it is suspected that there is an effect between learning culture on the self-efficacy of special intelligent students. The purpose of this study was to collect empirical data about the effect of learning culture on the selfefficacy of special intelligent students. This research is expected to be able to encourage special intelligent students, teachers, parents, and schools to maximize their role in forming a good learning culture for special intelligent students so that their self-efficacy can increase and they are more confident in their ability to achieve optimal learning outcomes and overcome existing learning challenges and problems.

\section{Method}

This research uses descriptive quantitative method (Bloomfield \& Fisher, 2019). The choice of this method is based on the need to analyze quantitative data based on statistical procedures so that understanding and meaning can be drawn. The location of this research was carried out at SMAN 78 Jakarta which is located in Komplek Pajak, Kemanggisan, West Jakarta.

The population that will be used is 47 special intelligent students. The researcher chose the Simple Random Sampling technique by taking random sample members without regard to the existing strata in the population. From a total of 47 students, the researcher determined the sample by using the sample size determination table developed by Isaac \& Michael, which is to calculate the sample with an error rate of $5 \%$ so that a sample of 42 special intelligent students will be used in the study.

Data were collected using questionnaires, interviews, and documentation studies. Questionnaires were distributed to 42 special intelligent students using the form of choice of a Likert scale score, namely 4 alternative answers, while interviews and documentation studies were only complementary techniques in data collection. To help the calculation, the researcher used IBM SPSS Statistics version 22. From the results of the validity test of each variable, the invalid items were then dropped and the valid items were used for research testing.

The results of the reliability test of the Learning Culture questionnaire instrument obtained Cronbach's Alpha $0.980>0.6$, which means that the learning culture instrument (variable X) can be said to be reliable. While the results of the reliability test of the self-efficacy questionnaire instrument obtained Cronbach's Alpha $0.982>0.6$, which means that the self-efficacy instrument of special intelligent students (variable Y) is reliable.

The data analysis technique used is descriptive analysis to analyze the data by describing the data that has been successfully collected from each of the variables studied so that it is easier to understand. Then the prerequisite test was carried out, namely the normality test using the Kolmogorov-Smirnov test and the linearity test. Then, the hypothesis was tested by correlation test, simple linear regression test, and coefficient of determination test.

The correlation test used is the Product Moment Correlation or Pearson Correlation to determine the relationship between two variables, which measures how strong the relationship is, the direction of the relationship is positive or negative, and to determine whether the relationship is significant or not (Duwi Priyatno, 2010). To predict how the effect of the independent variable on the dependent variable after it is known that there is a relationship between these variables, it is analyzed by regression (Sugiyono, 2018). Regression analysis is an advanced analysis of correlation. Simple linear regression analysis was used to test the extent of the effect between variable $\mathrm{X}$ on variable $\mathrm{Y}$, whether it had a positive or negative effect, and also to predict whether the value of the variable experienced an increase or decrease. Then the coefficient of determination is tested to interpret the Pearson Correlation score by squaring the score, so that it is known how much the $\mathrm{X}$ variable contributes to the $\mathrm{Y}$ variable when multiplied by $100 \%$.

\section{Results and Discussions}

\section{Descriptive Analysis}

The variables in this study are variable X (Learning Culture) and variable Y (Self-Efficacy of Special Intelligent Students). This study uses data collection techniques in the form of a questionnaire. Research questionnaires were distributed to 42 special intelligent students, consisting of 48 questions on variable $\mathrm{X}$ and 42 questions on variable $\mathrm{Y}$. 


\section{Data of Learning Culture}

Based on the calculation, it can be seen that the average value (mean) of the variable $\mathrm{X}$ (Learning Culture) is 148.02 , the median value (median) is 150.00 , there are several values that appear most often (mode) namely $134,143,154,161$, the standard deviation value is 14,129 , the minimum value is 107 , and the maximum value is 172 , so that the frequency distribution table grouping it shows on table 1.

Table 1. Variable Frequency Distribution of Learning Culture

\begin{tabular}{cccccc}
\hline & Frequency & Percent (\%) & Valid Percent (\%) & Cumulative Percent (\%) \\
\hline Valid & $107-117$ & 2 & 4,8 & 4,8 & 4,8 \\
& $118-128$ & 1 & 2,4 & 2,4 & 7,1 \\
& $129-139$ & 8 & 19,0 & 19,0 & 26,2 \\
$140-150$ & 11 & 26,2 & 26,2 & 52,4 \\
$151-161$ & 13 & 31,0 & 31,0 & 83,3 \\
$162-172$ & 7 & 16,7 & 16,7 & 100,0 \\
& Total & $\mathbf{4 2}$ & $\mathbf{1 0 0 , 0}$ & $\mathbf{1 0 0 , 0}$ & \\
\hline
\end{tabular}

Resource: Results of SPSS Research Data Processing Ver.22, 2021.

Furthermore, to determine the level of tendency or the level of the variable $\mathrm{X}$ (Learning Culture) using the average value (mean) and standard deviation with SPSS, the following results are obtained.

Table 2. Tendency Level of Data Variable of Learning Culture

\begin{tabular}{cccccc}
\hline & & Frequency & Percent (\%) & Valid Percent (\%) & Cumulative Percent (\%) \\
\hline Valid & Rendah & 3 & 7,1 & 7,1 & 7,1 \\
& Sedang & 32 & 76,2 & 76,2 & 83,3 \\
& Tinggi & 7 & 16,7 & 16,7 & 100,0 \\
& Total & 42 & 100,0 & 100,0 & \\
\hline
\end{tabular}

Resource: Results of SPSS Research Data Processing Ver.22, 2021.

Based on the table above, it can be seen that the score for the variable X (Learning Culture) included in the low category was 3 people (7.1\%), the medium category was 32 people $(76.2 \%)$, and the high category was 7 people $(16,7 \%)$. Based on these scores, it can be concluded that the learning culture of special intelligent students at SMAN 78 Jakarta is in the medium category.

\section{Self-Efficacy of Special Intelligent Students}

Data on self-efficacy of special intelligent students were obtained from the results of questionnaires distributed to 42 special intelligent students in this study. The researcher used IBM SPSS Statistics version 22 to help the calculation, with the following results. Based on the calculation, it can be seen that the average value (mean) of the variable Y (Self-Efficacy of Special Smart Students) is 126.36, the median value is 126.50 , there are several values that appear most often (mode) namely 122, 126, 127, 132, 135, the standard deviation value is 14,417 , the minimum value is 89 , and the maximum value is 161 , so that the frequency distribution table grouping is as follows.

Table 3. Variable Frequency Distribution of Self-Efficacy

\begin{tabular}{cccccc}
\hline & Frequency & Percent (\%) & Valid Percent (\%) & Cumulative Percent (\%) \\
\hline Valid & $89-99$ & 2 & 4,8 & 4,8 & 4,8 \\
& $100-110$ & 3 & 7,1 & 7,1 & 11,9 \\
$111-121$ & 9 & 21,4 & 21,4 & 33,3 \\
$122-132$ & 16 & 38,1 & 38,1 & 71,4 \\
$133-143$ & 8 & 19,0 & 19,0 & 90,5 \\
$144-154$ & 2 & 4,8 & 4,8 & 95,2 \\
$155-165$ & 2 & 4,8 & 4,8 & 100,0 \\
Total & 42 & 100,0 & 100,0 & \\
\hline
\end{tabular}

Resource: Results of SPSS Research Data Processing Ver.22, 2021.

Furthermore, to determine the level of tendency or the level of the variable X (Learning Culture) using the average value (mean) and standard deviation with the help of SPSS, the following results are obtained. 
Table 4. Tendency Level of Data Variable of Self-Efficacy

\begin{tabular}{lllccl}
\hline & Frequency & Percent (\%) & Valid Percent (\%) & Cumulative Percent (\%) \\
\hline Valid & Rendah & 5 & 11,9 & 11,9 & 11,9 \\
& Sedang & 32 & 76,2 & 76,2 & 88,1 \\
& Tinggi & 5 & 11,9 & 11,9 & 100,0 \\
& Total & 42 & 100,0 & 100,0 & \\
\hline
\end{tabular}

Resource: Results of SPSS Research Data Processing Ver.22, 2021.

Based on the table above, it can be seen that the variable score of Y (Self-Efficacy of Special Intelligent Students) which is included in the low category is 5 people (11.9\%), the medium category is 32 people $(76.2 \%)$, and the high category is 5 people. people $(11.9 \%)$. Based on these scores, it can be concluded that the selfefficacy of special intelligent students is in the medium category.

Based on the analysis that has been done, it can be concluded that learning culture has an effect of $68.6 \%$ on the self-efficacy of special intelligent students at SMAN 78 Jakarta. The results of an interview with the Deputy Head of Student Affairs at SMAN 78 Jakarta stated that there was indeed some effect between learning culture and the self-efficacy of special intelligent students. The better the student's study habits, the more confident he will be in his ability to complete two years of service. In following the two-year service, a special intelligent student cannot rely solely on IQ without having good study habits, because he will be stuck in the two-year service and harm himself.

The same thing was conveyed by the Guidance and Counseling teacher at SMAN 78 Jakarta, he said that the self-efficacy or self-confidence possessed by special intelligent students really started from the culture or study habits of the individual. If he has good study habits, it will make him more confident. Good study habits are very important for special intelligent students, because the main capital is only that. If the student does not study regularly, learn according to the mood, learn if there is only a test, of course you can't. The student will not be able to catch up with the module, if there is he will be stressed and unable to survive. So, good study habits are the main capital so that special intelligent students feel confident in their abilities. In line with this, Pak Harry as Deputy Head of Curriculum Sector at SMAN 78 Jakarta also said that on average, special intelligent students who survive and successfully complete services and years and achieve their goals are those who have good study habits, are tough in learning, are tenacious, and committed.

The factors that effect self-efficacy is cultural factors. Culture obtained through the learning process by a person or group of people in their environment can develop into a learning culture (Bandura, Freeman, \& Lightsey, 1999; Bandura, 2006). So it can be interpreted that the learning culture of special intelligent students can be one of the factors that affect self-efficacy, this is reinforced by the results of research showing that learning culture has an effect of $68.6 \%$ on the self-efficacy of special intelligent students at SMAN 78 Jakarta.

\section{Conclusions}

The conclusion is there is a contribution between learning culture to the self-efficacy of special intelligent students at SMAN 78 Jakarta. That is, the better the application of learning culture, the higher the self-efficacy of special intelligent students. Given the scale of cultural effects on self-efficacy study smart student special, special smart students are expected to adopt a good learning culture that will not experience excessive stress and able to deal with pressure well in following the accelerated learning services. That way it will increase selfefficacy or self-confidence in their abilities and potential and make students not easy to give up. Special intelligent students who have high self-efficacy will be able to independently deal with existing problems, including in completing tasks with their abilities. Students will not experience excessive stress when they are able to measure the extent of their abilities and can unleash their potential optimally, so that students will be able to deal with pressures well because they have full commitment and awareness of their responsibilities as learning subjects.

\section{References}

Alwisol. 2019. Psikologi Kepribadian Edisi Revisi. Malang: UMM Press.

Ansori, Miksan. 2015. Panduan Analisis Manual Penelitian Kuantitatif. Ngawi: Sekolah Tinggi Ilmu Tarbiyah Muhammadiyah.

Arif, Saiful. 2011. "Budaya Belajar Siswa Pada Sekolah Unggul di SMA Negeri 1 Pamekasan”. Jurnal Nuansa. 8(2): 190.

Arikunto, Suharsimi. 2013. Prosedur Penelitian Suatu Pendekatan Praktik. Jakarta: Rineka Cipta. 
Aziz, Mursal. 2017. "Manajemen Kurikulum dalam Pengembangan Budaya Belajar di Madrasah Aliyah Mu'Allimin Unia Medan", Jurnal Pendidikan ITTIHAD, 1(2): 203-304.

Baharuddin. 2016. Pendidikan \& Psikologi Perkembangan. Jogjakarta: Ar Ruzz Media.

Bandura, A. (2006). Guide for constructing self-efficacy scales. Self-efficacy beliefs of adolescents, 5(1), 307337.

Bandura, A., Freeman, W. H., \& Lightsey, R. (1999). Self-efficacy: The exercise of control: Springer.Bloomfield, J., \& Fisher, M. J. (2019). Quantitative research design. Journal of the Australasian Rehabilitation Nurses Association, 22(2), 27-30.

Eva, Nur dan Moh. Bisri. 2018. Kesejahteraan Psikologis Siswa Cerdas Istimewa. Malang: Universitas Negeri Malang.

Ghufron, M. dan Rini Risnawita. 2012. Teori-teori Psikologi. Jogjakarta: Ar-Ruzz Media.

Handayani, Febrina dan Desi Nurwidawati. 2013. "Hubungan Self Efficacy Dengan Prestasi Belajar Siswa Akselerasi”. Jurnal Penelitian Psikologi, 1(2).

Hery Yoenanto, Nono. 2010. "Hubungan antara Self-Regulated Learning dengan Self-Efficacy pada Siswa Akselerasi Sekolah Menengah Pertama di Jawa Timur". INSAN, 12(2): 89.

Kartika Dewi, Warni. 2015. "Evaluasi Pelaksanaan Program Cerdas Istimewa (CI) Akselerasi di SMA Negeri 5 Yogyakarta". Jurnal Manajemen Pendidikan.

Koentjaraningrat. 2009. Pengantar Ilmu Antropologi. Jakarta: Rineka Cipta.

Maria, Julia dan Endang Widyorini. 2014. Deteksi dan Penanganan Anak Cerdas Istimewa (Anak Gifted) Melalui Pola Alamiah Tumbuh Kembangnya. Jakarta: Prenada Media Group.

Maya Sari, Wanda. "Perbandingan Distribusi Frekuensi Antara Metode Sturges dan Scott". Jurnal Saintia Matematika, (20)20: 9.

Merdekawaty, Ana dan Fatmawati. 2019. "Pengaruh Kemandirian Belajar Dan Efikasi Diri Terhadap Pemahaman Akuntansi Siswa". Jurnal Ilmiah Pendidikan Ekonomi Fakultas Keguruan dan Ilmu Pendidikan, 7(2): 97.

Mukhid, Abd. 2009. "Self-Efficacy: Perspektif Teori Kognitif Sosial dan Implikasinya Terhadap Pendidikan". Tadrîs, 4(1): 108.

Nurhastuti. 2018. "Tes Potensi Anak Cerdas Istimewa dan Berbakat Istimewa". Sketsa Pendidikan Jurnal Pendidikan dan Kebudayaan, 3(I): 12.

Nugraha, Hafiz dan Ambiyar. 2018. "Pengaruh Budaya Belajar Terhadap Hasil Belajar Keterampilan Komputer dan Pengelolaan Informasi Siswa Sekolah Menengah Kejuruan Muhammadiyah 1 Padang". Jurnal Inovasi Vokasional dan Teknologi, 18(2): 49.

Permana, Hara, Farida Harahap, dan Budi Astuti. 2016. "Hubungan Antara Efikasi Diri dengan Kecemasan dalam Menghadapi Ujian pada Siswa Kelas IX di MTs Al Hikmah Brebes". Jurnal Hisbah, 13(1): 58-59

Priyatno, Duwi. 2010. Teknik Mudah dan Cepat Melakukan Analisis Data dengan SPSS. Yogyakarta: Gava Media.

Renzulli, J. S. (2002). Emerging conceptions of giftedness: Building a bridge to the new century. Exceptionality, 10(2), 67-75.

Renzulli, J. S. (2012). Reexamining the role of gifted education and talent development for the 21st century: A four-part theoretical approach. Gifted child quarterly, 56(3), 150-159.

Renzulli, J. S., \& D'Souza, S. (2014). Intelligences outside the normal curve: Co-cognitive factors that contribute to the creation of social capital and leadership skills in young people. Critical issues and practices in gifted education: What the research says, 343-362.Rosadi, Nanang dan Iwan Wahyu Widayat. 2013. "Hubungan antara Perfeksionisme dengan Depresi pada Siswa Cerdas Istimewa di Kelas Akselerasi". Jurnal Psikologi Pendidikan dan Perkembangan, 2 (1): 2.

Rusyan, Tabrani. 2007. Budaya Belajar yang Baik. Jakarta: PT Panca Anugerah Sakti.

Saipul Hidayat, Deden dan Wawan Gunawan. 2013. Mengembangkan Pendidikan Bagi Peserta Didik Cerdas Istimewa dan Bakat Istimewa CIBI. Jakarta: PT Luxima Metro Media.

Siregar, Syofian. 2011. Statistika Deskriptif untuk Penelitian: Dilengkapi Perhitungan Manual dan Aplikasi SPSS. Jakarta: PT RajaGrafindo Persada.

Slameto. 2018. Belajar dan Faktor-faktor yang Mempengaruhinya. Jakarta: Rineka Cipta.

SMAN 78 Jakarta, sman78-jkt.sch.id.

Soekanto, Soerjono. 2013. Sosiologi Suatu Pengantar. Jakarta: PT.RajaGrafindo Persada.

Sufirmansyah. 2015. "Pengaruh Efikasi Diri Terhadap Prestasi Belajar Mahasiswa Pascasarjana Prodi PAI STAIN Kediri dengan Motivasi Sebagai Variabel Intervening", Jurnal Didaktika Religia, 3(2): 143.

Sugiarti, Rini. 2019. Karakteristik Siswa Cerdas Istimewa. Banyumas: CV. Pena Persada.

Sugiyono. 2016. Metode Penelitian Kuantitatif, Kualitatif, dan R\&D. Bandung: Alfabeta.

Susanti, Tri. 2015. "Profil Empati Siswa Cerdas Istimewa di SMA Negeri Kota Yogyakarta". Jurnal Konseling Komperhensif, 2(1): 25. 
Suseno, Miftahun Ni'mah. 2009. "Pengaruh Pelatihan Komunikasi Interpersonal Terhadap Efikasi Diri sebagai Pelatih pada Mahasiswa". Jurnal Intervensi Psikologi. 1(1): 95.

Susetyo, Budi. 2010. Statistika untuk Analisis Data Penelitian. Bandung: PT Refika Aditama.

Tim Pengembang Ilmu Pendidikan FIP UPI. 2009. Ilmu dan Aplikasi Pendidikan Jilid 1. Bandung: PT. Imperial Bhakti Utama.

Winarto dan Lantip Diat P. 2017. "Strategi Pengembangan Budaya Pembelajaran di Sekolah". Jurnal Akuntabilitas Manajemen Pendidikan. 5(1): 114.

Wulandari, Silvia dan Mira Aliza. 2014. "Efikasi Diri dan Stress Akademik pada Siswa SMA Program Akselerasi". Psikologika, 19(2): 152. 